\title{
Peran Kortikosteroid dalam Pencegahan Stridor Pasca-ekstubasi pada Anak
}

\author{
Rismala Dewi, Cahyani Gita Ambarsari \\ Departemen Ilmu Kesehatan Anak, Fakultas Kedokteran Universitas Indonesia - RS Dr. Cipto Mangunkusumo, \\ Jakarta
}

\begin{abstract}
Stridor pasca-ekstubasi merupakan tanda obstruksi jalan napas atas akibat inflamasi yang terjadi pada tindakan intubasi. Inflamasi ini menimbulkan risiko untuk perlunya reintubasi dalam 24-48 jam pascaekstubasi, sehingga memperpanjang lama rawat pasien di unit perawatan intensif, meningkatkan risiko terjadinya berbagai penyulit akibat penggunaan ventilator mekanis, dan meningkatkan mortalitas. Pada contoh kasus ini, pasien mengalami intubasi berulang sebanyak tiga kali dengan lama tiap-tiap penggunaan intubasi adalah 5 hari, dan ada riwayat kesulitan intubasi pada tindakan intubasi pertama. Pasca-ekstubasi yang pertama, pasien mengalami sesak dan stridor sehingga reintubasi diperlukan. Riwayat kortikosteroid profilaksis sebelum ekstubasi tidak diketahui. Dengan mempertimbangkan adanya riwayat intubasi sulit serta durasi intubasi $>48$ jam, pasien ini berisiko mengalami kegagalan ekstubasi, sehingga pemberian kortikosteroid profilaksis sebelum ekstubasi diharapkan akan bermanfaat. Pada pasien anak, belum ada bukti berbasis medik yang memadai untuk menyimpulkan bahwa pemberian kortikosteroid profilaksis sebelum ekstubasi elektif akan mencegah stridor pasca-ekstubasi. Telaah dari studi yang heterogen dengan metodologi yang kurang memadai seperti dalam ulasan ini cenderung hanya melaporkan efek terapi, tetapi belum dapat digunakan sebagai suatu pedoman. Beberapa studi menunjukkan peran kortikosteroid menghasilkan keluaran yang baik. Deksametason IV yang diberikan beberapa jam sebelum dan sesudah ekstubasi pada anak, termasuk pada pasien dengan riwayat kegagalan intubasi, akan mengurangi risiko terjadinya stridor pasca-ekstubasi. Sari Pediatri 2011;13(1):14-20.
\end{abstract}

Kata kunci: stridor, ekstubasi, kortikosteroid

I ntubasi endotrakea adalah prosedur yang sering dikerjakan di unit perawatan intensif (Intensive Care Unit (ICU)). Ulserasi dan edema reaktif (inflamasi) pada mukosa glotis dan subglotis

\footnotetext{
Alamat korespondensi:

Dr. Rismala Dewi, Sp.A. Divisi Pediatri Gawat Darurat Departemen IKA FKUI-RSCM. Jl. Diponegoro no. 71 Jakarta Pusat. Telp. 0811810112, Fax: 021-3907743. E-mail: dewi_sumitro@yahoo.com
}

dapat terjadi akibat trauma pada tindakan intubasi itu sendiri dan akibat penekanan atau iritasi oleh pipa endotrakea. Inflamasi ini menyebabkan obstruksi jalan napas atas yang ditandai dengan stridor, ${ }^{1}$ sehingga berisiko untuk terjadinya kegagalan ekstubasi, yaitu perlunya reintubasi dalam 24-48 jam pasca-ekstubasi. ${ }^{2,3}$ Tindakan reintubasi ini berarti akan memperpanjang lama rawat di ICU, meningkatkan risiko terjadinya berbagai penyulit akibat penggunaan ventilator mekanis, dan meningkatkan mortalitas. ${ }^{4,5}$ 
Pada pasien di ICU anak (Pediatric ICU (PICU)) yang diintubasi karena berbagai sebab, sebanyak $37 \%$ mengalami kegagalan ekstubasi akibat obstruksi jalan napas atas dan $14 \%$ di antaranya memerlukan trakeostomi. ${ }^{5}$

Kortikosteroid dengan kemampuan antiinflamasinya selama ini digunakan secara parenteral untuk mencegah atau mengatasi stridor pasca-ekstubasi, tetapi sebenarnya penggunaan kortikosteroid secara rutin untuk kedua tujuan ini masih kontroversi karena belum ada bukti sahih yang mendukung manfaat kortikosteroid, terutama pada populasi pasien anak. Beberapa studi menggunakan kortikosteroid mulai dari 6-24 jam sebelum tindakan ekstubasi elektif sebagai profilaksis stridor pasca-ekstubasi, ${ }^{5-7}$ sementara ada studi lain yang memberi kortikosteroid sebagai terapi, setelah terbukti terjadi stridor pasca-ekstubasi ${ }^{2}$. Tujuan laporan kasus berbasis bukti ini adalah untuk mengevaluasi efektivitas kortikosteroid parenteral sebagai profilaksis stridor pasca-ekstubasi.

\section{Kasus}

Seorang anak laki laki, berusia 7 tahun 7 bulan, datang ke Instalasi Gawat Darurat (IGD) Rumah Sakit Cipto Mangunkusumo (RSCM) tanggal 4 Januari 2010. Pasien datang dengan keluhan utama sesak yang memberat sejak 5 hari sebelum masuk ke rumah sakit (SMRS). Pasien dirujuk dari RSAL $M$ dengan keterangan edema laring. Tiga minggu SMRS (15 Desember 2009) pasien menjalani tonsiloadenoidektomi (TA) di RS PR kemudian pulang pada hari yang sama setelah observasi di ruang rawat sehari. Tindakan TA berlangsung tanpa penyulit dan pasien pulang dalam kondisi baik.

Satu hari pasca-TA pasien merasa sulit bernapas dan suara terdengar parau sehingga ibu membawa pasien ke RS HK. Pasien memperoleh terapi inhalasi sebanyak 2 kali tetapi tidak ada perbaikan, sesak semakin berat, dan suara napas tedengar seperti mengorok sehingga pasien diintubasi. Tindakan intubasi saat itu sulit. Pasien menjalani perawatan dalam keadaan terintubasi dan memperoleh terapi oksigen menggunakan T-piece di PICU selama 5 hari (17-21 Desember 2009). Pasien pulang setelah menjalani perawatan selama 2 hari (2223 Desember 2009) di ruang rawat biasa dan sesak berkurang. Penggunaan kortikosteroid dan antibiotik selama perawatan tidak diketahui.
Selama di rumah pasien masih mengalami sesak yang hilang timbul. Pasien merasa kesulitan bernapas dan memerlukan usaha napas yang dalam serta suara napas terdengar seperti mengorok. Karena sesak memberat, pasien dibawa kembali ke RS HK, diintubasi, dan dirawat di PICU. Diagnosis pasien saat dirawat adalah edema laring. Pasien pulang pascaekstubasi (30 Desember 2010) setelah 5 hari dirawat dalam kondisi sesak yang membaik. Penggunaan kortikosteroid dan antibiotik selama perawatan tidak diketahui.

Lima hari SMRS (31 Desember 2009) sesak kembali memberat sehingga ibu membawa pasien ke RS terdekat, yaitu RSAL M. Pasien kembali diintubasi dan dirawat di PICU. Dokter di RSAL M menyarankan trakeostomi tetapi ibu menolak. Pasien memperoleh terapi oksigen $9 \mathrm{~L} /$ menit, sefotaksim IV 2 x 1 g, amikasin IV 1 x 250 mg, deksametason IV 3 x 10 mg, serta inhalasi 3 kali/hari dengan Pulmicort ${ }^{\circledR}$ dan Ventolin ${ }^{\circledR}$. Setelah perawatan selama 5 hari di PICU RSAL M, ibu meminta pasien dirujuk ke RSCM.

Pada riwayat penyakit dahulu, pasien mengalami tonsilitis berulang yang frekuensinya makin sering dalam 1 tahun terakhir sehingga pasien dianjurkan menjalani TA. Riwayat Obstructive Sleep Apnea Syndrome (OSAS) dan atopi disangkal. Pasien duduk di kelas II sekolah dasar, imunisasi dasar lengkap, dan konsumsi nutrisi kesan berlebih.

Pada pemeriksaan fisis saat datang ke IGD pasien kompos mentis, tidak sianosis, tetapi tampak sesak. Pasien terintubasi dengan endotracheal tube (ETT) ukuran $5,5 \mathrm{~mm}$, kedalaman $13,5 \mathrm{~cm}$, dengan oksigen T-piece $6 \mathrm{~L} /$ menit. Saat itu ssaturasi oksigen 91\%, laju napas pasien $30 \mathrm{kali} / \mathrm{menit}$, laju nadi $91 \mathrm{kali} / \mathrm{menit}$, teratur, dengan isi cukup. Tekanan darah 120/60 $\mathrm{mmHg}$ dan suhu badan $36,8^{\circ} \mathrm{C}$. Berat badan (BB) $37 \mathrm{~kg}$ dan tinggi badan (TB) $125 \mathrm{~cm}$ (antropometri sesuai dengan obesitas). Klinis pasien juga sesuai dengan obesitas (pipi tembem, leher pendek, payudara membesar, abdomen tampak buncit, dan jaringan lemak subkutan tebal). Bunyi napas terdengar vesikular dengan ronki basah kasar pada kedua lapang paru dan tanpa mengi.

Pemeriksaan laboratorium di RSAL M menunjukkan kadar hemoglobin $14 \mathrm{~g} / \mathrm{dl}$, hematokrit $42 \mathrm{vol} \%$, leukosit $10700 / \mu \mathrm{l}$, dan trombosit $284000 / \mu \mathrm{l}$. Analisis gas darah dalam oksigenasi T-piece (tidak diketahui kadar oksigen yang diberikan) menunjukkan $\mathrm{pH}$ 7,405, $\mathrm{pCO}_{2} 43,7 \mathrm{mmHg}, \mathrm{pO}_{2} 154,4 \mathrm{mmHg}, \mathrm{HCO}_{3}$ 
27,1 $\mathrm{mmol} / \mathrm{L}$, BE 1,6, saturasi 99\%, natrium 141 $\mathrm{mEq} / \mathrm{L}$, kalium 4,16 mEq/L, dan klorida $94 \mathrm{mEq} / \mathrm{L}$.

Pasien didiagnosis obstruksi jalan napas atas karena edema laring dan obesitas. Pasien menjalani perawatan di PICU, mendapat terapi oksigen menggunakan T-piece, diet makanan cair $8 \times 250 \mathrm{~mL}$ melalui pipa nasogastrik, deksametason IV 4 x $5 \mathrm{mg}$, seftriakson IV $1 \mathrm{x} 1 \mathrm{~g}$, dan ranitidin IV $3 \times 10 \mathrm{mg}$. Pasien menjalani bronkoskopi, laringoskopi, dan trakeostomi pada hari rawat ke-4. Hasil tindakan laringoskopi menunjukkan adanya jaringan granulasi di komisura posterior serta plica vocalis dan plica ventricularis edema dan hiperemis, berbentuk iregular terutama di bagian posterior, dan dapat bergerak simetris meskipun terbatas. Trakea tampak edema, menyempit, dan hiperemis.

\section{Formulasi pertanyaan klinis}

Kontroversi mengenai penggunaan kortikosteroid parenteral sebelum dan sesudah tindakan ekstubasi telah berlangsung sejak dahulu. Sejauh ini, keputusan dan pilihan memberikan kortikosteroid parenteral untuk mencegah edema laring masih banyak didasarkan atas keputusan empiris seperti halnya pada pasien ini. Untuk itu diajukan pertanyaan klinis sebagai berikut: "pada anak yang mengalami intubasi endotrakea, apakah pemberian kortikosteroid parenteral sebagai profilaksis (sebelum ekstubasi) dibandingkan tanpa kortikosteroid profilaksis, dapat mencegah terjadinya stridor pasca-ekstubasi?”

\section{Metode/strategi penelusuran bukti}

Penelusuran dimulai untuk mencari bukti sekunder berupa meta-analisis, telaah sistematik, ataupun guidelines berbasis bukti sistematik pada situs Cochrane Systematic Database Review, Bandolier (http://www. medicine.ox.ac.uk/bandolier), dan ACP Journal Club (bttp://www.acpjc.org/) dengan memakai kata kunci "extubation" dan menghasilkan 22 artikel. Pada ketiga situs tersebut hanya ditemukan tiga artikel mengenai penggunaan kortikosteroid untuk mencegah stridor pasca-ekstubasi. Setelah dilakukan penelaahan lebih lanjut terhadap judul dan abstrak, dua artikel (keduanya berupa telaah sistematik) dianggap relevan, sedangkan satu artikel dieksklusi karena studi dilakukan hanya pada pasien dewasa.

Penelusuran bukti primer dilakukan menggunakan mesin pencari TRIP database (www.tripdatabase.com) dan Pubmed. Pada pencarian dengan TRIP database dan Pubmed mempergunakan kata kunci "corticosteroid", "extubation", dan "stridor" diperoleh enampuluh tiga artikel. Setelah dilakukan penelaahan lebih lanjut terhadap judul dan abstrak, enam artikel dianggap relevan, sedangkan limapuluh tujuh dieksklusi karena studi dilakukan pada populasi dewasa, ketidakjelasan metodologi, atau isi yang tidak relevan. Enam studi tersebut terdiri atas meta-analisis $(\mathrm{n}=1)$, uji klinis acak terkontrol $(\mathrm{n}=3)$, dan studi kasus-kontrol $(\mathrm{n}=2)$.

Levels of evidence ditentukan berdasarkan klasifikasi yang dikeluarkan oleh Oxford Centre for Evidence-based Medicine Levels of Evidence. ${ }^{8}$ Karena mengutamakan studi dengan level of evidence 1, hanya enam studi yang dianalisis pada tulisan ini, yang terdiri atas telaah sistematik $(\mathrm{n}=2)$, meta-analisis $(\mathrm{n}=1)$, dan uji klinis acak terkontrol $(\mathrm{n}=3)$.

\section{Hasil penelusuran}

Tabel 1 menunjukkan enam studi dengan level of evidence 1 yang dipublikasi dalam 20 tahun terakhir (1991 sampai sekarang). Keluaran yang diteliti serupa yakni kejadian stridor pasca-ekstubasi dan reintubasi, namun secara keseluruhan tidak ada studi yang konsisten menyimpulkan bahwa kortikosteroid profilaksis terbukti mencegah stridor pasca-ekstubasi.

Telaah sistematik Khemani $\mathrm{dkk}^{9}$ (2009) melaporkan dari enam studi pada populasi dewasa $(\mathrm{n}=1953)$, kortikosteroid profilaksis menurunkan insidens stridor pasca-ekstubasi secara bermakna (RR 0,47; IK95\% 0,22 sampai 0,99), dan lebih bermanfaat bila diberikan dengan dosis multipel selama 12-24 jam sebelum ekstubasi (RR 0,22; IK95\% 0,1 sampai 0,47) dibandingkan dengan dosis tunggal.

Dalam empatbelas studi yang dianalisis dalam telaah sistematik McCaffrey dkk, ada empat jenis kortikosteroid yang digunakan. Studi pada neonatus menggunakan deksametason $(\mathrm{n}=3)$, studi pada anak menggunakan deksametason $(\mathrm{n}=3)$ dan prednisolon $(\mathrm{n}=1)$, dan studi pada dewasa menggunakan deksametason $(n=3)$, metilprednisolon $(\mathrm{n}=3)$, dan hidrokortison $(\mathrm{n}=2)$. Tabel 2 menunjukkan rentang dosis kortikosteroid yang diterapkan dalam empat studi pada populasi anak.

Anene $\mathrm{dkk}^{6}$ (1996) dan Harel dkk (1997) $^{5}$ mengevaluasi manfaat deksametason IV profilaksis terhadap insidens stridor pasca-ekstubasi dan atau kejadian reintubasi, di antaranya termasuk pada pasien 
Rismala Dewi dkk: Peran kortikosteroid dalam pencegahan stridor pasca-ekstubasi pada anak

Tabel 1. Studi yang ditemukan pada penelusuran bukti berbasis medik

\begin{tabular}{|c|c|c|c|c|}
\hline Artikel & $\begin{array}{c}\text { Subyek } \\
\text { (jumlah subyek) }\end{array}$ & Intervensi & Keluaran & Hasil \\
\hline \multicolumn{5}{|c|}{$\begin{array}{l}\text { Level of evidence 1a } \\
\text { Telaah sistematik }\end{array}$} \\
\hline $\begin{array}{l}\text { Khemani dkk } \\
\text { (2009) }\end{array}$ & $\begin{array}{l}11 \text { uji klinis acak terkontrol } \\
\text { - } 2 \text { pada neonatus } \\
\text { - } 3 \text { pada anak } \\
\text { - } 6 \text { pada dewasa } \\
\text { (2301) }\end{array}$ & $\begin{array}{c}\text { Kortikosteroid parenteral } \\
\text { (IV, IM, atau inhalasi) } \\
\text { dalam berbagai dosis } \\
\text { vs } \\
\text { plasebo } \\
\text { dalam } 24 \text { jam sebelum \& sesudah } \\
\text { ekstubasi } \\
\text { Regimen terbanyak: deksametason } \\
\text { IV sekurang-kurangnya sekali } \\
\text { pra-ekstubasi. }\end{array}$ & $\begin{array}{l}\text { Efektivitas } \\
\text { kortikosteroid: } \\
\text { - Mencegah } \\
\text { stridor pasca- } \\
\text { ekstubasi } \\
\text { - Mengobati } \\
\text { stridor pasca- } \\
\text { ekstubasi }\end{array}$ & $\begin{array}{l}\text { 1) Secara keseluruhan pada neonatus, anak, \& } \\
\text { dewasa: kortikosteroid tidak mencegah maupun } \\
\text { mengobati stridor pasca-ekstubasi. } \\
\text { 2) Khusus studi pada anak: heterogen. } \\
\text { a) Studi yang menginklusi kelainan jalan napas } \\
\text { ( } \mathrm{n}=62 \text { ) } \\
\text { - Kortikosteroid profilaksis cenderung } \\
\text { mengurangi kejadian reintubasi. } \\
\text { - Kortikosteroid profilaksis mengurangi } \\
\text { stridor pasca-ekstubasi secara bermakna. } \\
\text { b) Studi yang mengeksklusi kelainan jalan napas } \\
\text { ( } \mathrm{n}=153) \text { : sebaliknya. }\end{array}$ \\
\hline $\begin{array}{l}\text { McCaffrey } \\
\text { dkk (2009) }\end{array}$ & $\begin{array}{l}14 \text { uji klinis acak terkontrol } \\
\text { - } 3 \text { pada neonatus } \\
\text { - } 4 \text { pada anak } \\
\text { - } 7 \text { pada dewasa } \\
\text { (2600) }\end{array}$ & $\begin{array}{c}\text { Kortikosteroid IV: deksametason } \\
\text { (8 studi), prednisolon (1 studi), } \\
\text { metilprednisolon ( } 3 \text { studi), } \\
\text { hidrokortison ( } 2 \text { studi) } \\
\text { dalam berbagai dosis } \\
\text { vs } \\
\text { plasebo } \\
\text { dalam } 24 \text { jam sebelum \& sesudah } \\
\text { ekstubasi. }\end{array}$ & $\begin{array}{l}\text { Efektivitas } \\
\text { kortikosteroid } \\
\text { menurunkan } \\
\text { reintubasi }\end{array}$ & $\begin{array}{l}\text { Secara keseluruhan pada neonatus, anak, \& dewasa: } \\
\text { 1) Kortikosteroid menurunkan reintubasi (RO 0,56; } \\
\text { IK95\% 0,41-0,77; } \mathrm{P}<0,0005 \text { ). Efek lebih jelas } \\
\text { pada studi yang memberi kortikosteroid } \geq 12 \text { jam } \\
\text { sebelum ekstubasi (RO 0,41; IK95\% 0,26-0,64). } \\
\text { 2) Kortikosteroid menurunkan kejadian edema } \\
\text { laring (RO 0,36; IK95\% 0,27-0,49; } \mathrm{P}<0,0005 \text { ). }\end{array}$ \\
\hline $\begin{array}{l}\text { Meta-analisis } \\
\text { Markovitz } \\
\text { dkk (2002) }\end{array}$ & $\begin{array}{l}6 \text { uji klinis acak terkontrol } \\
\text { - } 3 \text { pada neonatus } \\
\text { - } 3 \text { pada anak } \\
\text { (376) }\end{array}$ & $\begin{array}{c}\text { Deksametason parenteral } \\
\text { (IV, IM, atau inhalasi) } \\
\text { dalam berbagai dosis } \\
\text { vs } \\
\text { plasebo } \\
\text { dalam } 24 \text { jam sebelum \& sesudah } \\
\text { ekstubasi. }\end{array}$ & $\begin{array}{l}\text { Efektivitas } \\
\text { kortkosteroid: } \\
\text { - Mencegah } \\
\text { reintubasi } \\
\text { - Mencegah } \\
\text { stridor dalam } \\
6 \text { jam pasca- } \\
\text { ekstubasi }\end{array}$ & $\begin{array}{l}\text { 1) Secara keseluruhan pada neonatus \& anak: } \\
\text { a) Deksametason profilaksis menurunkan } \\
\text { reintubasi, tetapi tidak bermakna (RR 0,34; } \\
\text { IK95\% 0,05-2,33). } \\
\text { b) Deksametason profilaksis menurunkan } \\
\text { prevalens stridor pasca-ekstubasi (RR 0,50; } \\
\text { IK95\% 0,28-0,88) } \\
\text { 2) Khusus pada anak: } \\
\text { a) Deksametason profilaksis menurunkan } \\
\text { kejadian stridor pasca-ekstubasi (RR 0,53; } \\
\text { IK95\% 0,28-0,97) } \\
\text { b) Deksametason profilaksis menurunkan } \\
\text { reintubasi tetapi tidak bermakna (RR 0,55; } \\
\text { IK95\% 0,17-1,78). }\end{array}$ \\
\hline
\end{tabular}

Level of evidence $1 \mathrm{~b}$

Uji klinis acak terkontrol

Harel dkk Inklusi

(1997) Anak yang gagal ekstubasi karena stridor pasca-ekstubasi.

Eksklusi

Penggunaan steroid dalam 7 hari terakhir.

(26)

Anene dkk Inklusi

(1996) Pasien usia 1-59 bulan yang mengalami intubasi $>48$ jam, termasuk kelainan jalan napas.

Eksklusi

- Infeksi laringotrakea

- Penggunaan steroid dalam 7 hari terakhir

(63)

Tellez dkk Inklusi

(1991) Pasien PICU yang mengalami intubasi tanpa komplikasi.

Eksklusi

- Infeksi jalan napas atas

- Trauma operatif jalan napas atas

- Riwayat obstruksi jalan napas atas (153) ortikosteroid IV: deksametason Efektivitas hidrokortison (2 studi) vs
plasebo m sebelum \& sesudah ekstubasi.

eksametason parenteral (IV, IM, atau inhalasi)

$$
\text { vs }
$$
ekstubasi.

\author{
Deksametason IV Kejadian \\ $(0,5 \mathrm{mg} / \mathrm{kg})($ maks. $15 \mathrm{mg}) \quad$ reintubasi \\ pada: \\ 6 jam pra-ekstubasi (yang ke-2) \\ saat ekstubasi \\ $6 \& 12$ jam pasca-ekstubasi
Deksametason $0,5 \mathrm{mg} / \mathrm{kg}$ (maks $10 \mathrm{mg}$ ): mulai 6-12 jam pra-ekstubasi, \\ selanjutnya tiap 6 jam sampai 6 \\ dosis total.
- Kejadian reintubasi
- Kejadian stridor

Deksametason mencegah reintubasi pada pasien yang telah mengalami gagal ekstubasi, tetapi tidak bermakna (RR 0,55; IK95\% 0,17-1,78).

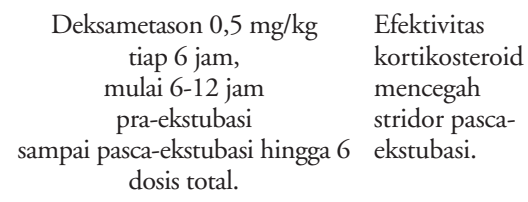

1) Kejadian reintubasi berkurang tetapi tidak bermakna (RR 0,07; IK95\% 0,001-1,15).

2) Kejadian stridor pasca-ekstubasi kelompok plasebo (87\%) vs kelompok obat (45\%).

3) Kejadian reintubasi kelompok plasebo (22\%) vs kelompok obat $(0 \%)$.

1) Tidak ada perbedaan insidens stridor pascaekstubasi antar kelompok.

2) Sebanyak $23 / 77$ kelompok plasebo \& $16 / 76$ kelompok deksametason memerlukan terapi karena stridor (RR 0,70; IK95\% 0,41-1,23; $\mathrm{P}=0,21)$.

maks: maksimal 
Rismala Dewi dkk: Peran kortikosteroid dalam pencegahan stridor pasca-ekstubasi pada anak

Tabel 2. Kortikosteroid dalam studi pada anak yang diintubasi

\begin{tabular}{|c|c|c|c|c|c|c|}
\hline Studi & $\begin{array}{l}\text { Karakteristik } \\
\text { populasi } \\
\text { (rerata usia) }\end{array}$ & $\begin{array}{l}\text { Rerata lama } \\
\text { penggunaan } \\
\text { intubasi } \\
\text { (hari) }\end{array}$ & Kortikosteroid & Dosis per kali & Waktu pemberian & $\begin{array}{c}\text { Dosis } \\
\text { kumulatif } \\
\text { (ekuivalensi } \\
\text { dalam } \\
\text { deksametason) }\end{array}$ \\
\hline $\begin{array}{l}\text { Harrel } \\
(1997)\end{array}$ & $\begin{array}{c}\text { Riwayat } \\
1 \text { kali gagal } \\
\text { ekstubasi } \\
\text { (34,6 bulan) }\end{array}$ & 21 & Deksametason & $\begin{array}{c}0,5 \mathrm{mg} / \mathrm{kg} \\
\text { (maks. } 15 \mathrm{mg} \text { ) }\end{array}$ & $\begin{array}{c}6 \text { jam pra-ekstubasi } \rightarrow \\
\text { selanjutnya tiap } 6 \text { jam, } 2 \\
\text { kali }\end{array}$ & $1,5 \mathrm{mg} / \mathrm{kg}$ \\
\hline $\begin{array}{l}\text { Anene } \\
(1996)\end{array}$ & $\begin{array}{l}\text { Pasien PICU } \\
(3,5 \text { bulan })\end{array}$ & $3,4^{*}$ & Deksametason & $\begin{array}{c}0,5 \mathrm{mg} / \mathrm{kg} \\
\text { (maks. } 10 \mathrm{mg})\end{array}$ & $\begin{array}{c}\text { 6-12 jam pra-ekstubasi } \rightarrow \\
\text { selanjutnya tiap } 6 \text { jam, } 5 \\
\text { kali }\end{array}$ & $3 \mathrm{mg} / \mathrm{kg}$ \\
\hline $\begin{array}{l}\text { Tibballs } \\
(1992)\end{array}$ & $\begin{array}{c}\text { Croup } \\
\text { (19 bulan) }\end{array}$ & 3,5 & Prednisolon & $1 \mathrm{mg} / \mathrm{kg}$ & $\begin{array}{c}\text { Tiap } 12 \text { jam } \\
\text { pasca-ekstubasi, } 2 \text { kali }\end{array}$ & bervariasi \\
\hline $\begin{array}{l}\text { Tellez } \\
(1991)\end{array}$ & $\begin{array}{l}\text { Pasien PICU } \\
(2,5 \text { tahun })\end{array}$ & 3,3 & Deksametason & $\begin{array}{c}0,5 \mathrm{mg} / \mathrm{kg} \\
\text { (maks. } 10 \mathrm{mg})\end{array}$ & $\begin{array}{c}\text { 6-12 jam pra-ekstubasi } \rightarrow \\
\text { selanjutnya tiap } 6 \text { jam, } 5 \\
\text { kali }\end{array}$ & $3 \mathrm{mg} / \mathrm{kg}$ \\
\hline
\end{tabular}

*Nilai dalam median

maks: maksimal

yang pernah mengalami kegagalan ekstubasi (akibat stridor pasca-ekstubasi). Tellez $\mathrm{dkk}^{7}$ (1991) meneliti peran kortikosteroid dalam pencegahan stridor pascaekstubasi pada pasien dengan riwayat kegagalan ekstubasi (akibat stridor pasca-ekstubasi). Dua studi menyimpulkan kortikosteroid profilaksis bermanfaat dalam pencegahan stridor pasca-ekstubasi ${ }^{10,11}$ tetapi empat studi lain melaporkan sebaliknya..$^{5-7,12}$

\section{Pembahasan}

Pasien yang mengalami intubasi dipertimbangkan siap menjalani ekstubasi atas dasar kriteria ventilasi yang spontan, hemodinamik yang stabil, refleks jalan napas yang adekuat, dan aliran sekret jalan napas yang baik. Suatu ekstubasi dinyatakan berhasil jika pasien mampu bernapas spontan selama 48 jam tanpa bantuan tekanan positif. Kegagalan ekstubasi dini adalah kesulitan bernapas spontan yang terjadi dalam 6 jam pertama, intermedia terjadi dalam 6-24 jam, dan lambat terjadi dalam 24-48 jam. ${ }^{2}$ Pasien rawat PICU yang memiliki risiko tinggi untuk mengalami kegagalan ekstubasi adalah pasien dengan usia $\leq 24$ bulan, durasi intubasi $>48$ jam, dan penyakit respiratorik. ${ }^{4}$

Kortikosteroid selama ini digunakan untuk menghindari kegagalan ekstubasi akibat obstruksi jalan napas karena edema laring. Kortikosteroid bermanfaat untuk mengatasi edema laring karena khasiat anti- inflamasinya, yaitu menghambat pelepasan mediator inflamasi dan menurunkan permeabilitas kapiler. Penggunaan kortikosteroid sebagai profilaksis obstruksi jalan napas sebenarnya masih menjadi kontroversi. ${ }^{2,4}$

Telaah sistematik dan meta-analisis yang ada mengevaluasi penggunaan kortikosteroid pada semua kelompok usia (neonatus, anak, dan dewasa). Telaah sistematik oleh Khemani $\mathrm{dkk}^{9}$ menyimpulkan bahwa kortikosteroid tidak terbukti efektif (secara statistik) untuk mencegah ataupun mengobati stridor pascaekstubasi pada semua kelompok usia, tetapi secara klinis cenderung menguntungkan dalam mencegah stridor pasca-ekstubasi.

Telaah sistematik oleh McCaffrey $\mathrm{dkk}^{11}$ menyimpulkan kortikosteroid profilaksis menurunkan kejadian edema laring dan reintubasi pada pasien neonatus, anak, dan dewasa yang dirawat di ICU secara bermakna (rasio odds (RO) 0,56; IK95\% 0,41 sampai 0,77; $\mathrm{P}<0,0005)$ ). Khusus pada populasi anak, McCaffrey dkk menganalisis 4 studi prospektif dan menyatakan bahwa pada pasien yang memperoleh kortikosteroid profilaksis, RO untuk reintubasi adalah 0,48 (IK95\% 0,25 sampai 0,93 ).

Meta-analisis oleh Markovitz $\mathrm{dkk}^{10}$ yang melibatkan populasi neonatus dan anak menyimpulkan kortikosteroid secara bermakna mengurangi kejadian stridor pasca-ekstubasi (risiko relatif (RR) 0,50; IK95\% 0,28 sampai 0,80 ) dan mengurangi kejadian reintubasi meskipun tidak bermakna secara statistik (RR 0,34; 
IK95\% 0,05 sampai 2,33).

Beberapa studi pada anak menunjukkan hasil yang bervariasi dan bahkan bisa sangat bertolak belakang (Tabel 3). Perbedaan ini disebabkan perbedaan kriteria inklusi, setting penelitian, durasi intubasi, serta dosis kortikosteroid yang digunakan. Studi prospektif Anene $\mathrm{dkk}^{6}$ menyimpulkan deksametason efektif mencegah stridor pasca-ekstubasi dan mencegah reintubasi akibat stridor pasca-ekstubasi.

Tellez $\mathrm{dkk}^{7}$ mengemukakan bahwa pada pasien rawat PICU yang mengalami intubasi tanpa penyulit, insidens stridor pasca-ekstubasi pada kelompok deksametason dibandingkan dengan kelompok plasebo tidak berbeda bermakna (RO 0,70; IK95\% 0,41-1,23; $\mathrm{P}=0,21$ ), sehingga penggunaan kortikosteroid tidak terbukti bermanfaat mencegah stridor pasca-ekstubasi. Khusus pada pasien yang sebelumnya telah mengalami kegagalan ekstubasi, Harel $\mathrm{dkk}^{12}$ melaporkan bahwa deksametason juga tidak terbukti efektif mencegah reintubasi.

Perbedaan hasil studi Anene dkk dengan studi Tellez dkk dapat terjadi karena perbedaan karakteristik populasi subyek. Dua kelompok pada studi Anene $\mathrm{dkk}^{6}$ ternyata berbeda dalam hal jumlah pasien yang tidak mengalami kebocoran pipa (tube leak) sementara tidak adanya tube leak selama ini digunakan sebagai salah satu prediktor stridor pasca-ekstubasi. Perbedaan ini menunjukkan distribusi karakteristik subyek yang tidak sebanding antara kedua kelompok. Dibandingkan dengan studi lainnya, subyek pada studi Anene dkk adalah pasien dengan risiko tinggi. Anene dkk juga menginklusi pasien dengan riwayat manipulasi jalan napas, termasuk reintubasi, sementara Tellez dkk mengeksklusi kelompok pasien tersebut.

Tabel 3. Perbandingan hasil studi

\begin{tabular}{lcc}
\hline Studi & $\begin{array}{c}\text { Stridor pasca-ekstubasi } \\
\text { (plasebo/obat) }(\%)\end{array}$ & $\begin{array}{c}\text { Reintubasi } \\
\text { (plasebo/obat) (\%) }\end{array}$ \\
\hline Tellez (1991) & $30 / 21$ & $5 / 12$ \\
Anene (1996) & $87 / 45$ & $22 / 0$ \\
Harel (1997) & tidak diteliti & $36 / 25$ \\
\hline
\end{tabular}

Tulisan ini mempunyai beberapa keterbatasan dalam menjawab pertanyaan klinis yang telah diformulasikan. Dalam tulisan ini, 2 telaah sistematik dan 1 meta-analisis yang dibahas melibatkan pasien pada semua kelompok usia, sehingga penggunaan analisis ketiga studi tersebut sebagai dasar untuk menjawab pertanyaan klinis kasus ini yaitu pada populasi pasien anak, adalah tidak tepat. Keterbatasan tulisan ini juga karena kriteria validasi telaah kritis tidak seluruhnya terpenuhi oleh ketiga uji prospektif yang digunakan. Tidak terpenuhinya kriteria validasi tersebut dapat melemahkan kesimpulan ulasan ini (Tabel 4).

Kasus dalam tulisan ini memiliki riwayat kesulitan intubasi pada tindakan intubasi yang pertama sehingga mungkin tindakan intubasi saat itu menimbulkan trauma. Penggunaan ETT pada intubasi pertama berlangsung selama 5 hari ( $>48$ jam), yang berarti merupakan satu faktor risiko kegagalan ekstubasi. Pemberian kortikosteroid parenteral sebagai profilaksis stridor pasca-ekstubasi tidak diketahui. Selanjutnya pasien mengalami manipulasi jalan napas atas multipel yaitu intubasi berulang, hal ini dapat memperberat edema laring yang telah terjadi sebelumnya.

Pada kondisi pasien ini dengan riwayat intubasi sulit dan durasi intubasi $>48 \mathrm{jam}$, pemberian kortikosteroid profilaksis seharusnya bermanfaat. Tindakan laringoskopi yang dilakukan pada hari rawat ke-4 menunjukkan terjadi respons inflamasi yang berat pada area glotis dan subglotis sehingga menjelaskan penyebab manifestasi suara parau serta kesulitan bernapas pada pasien ini. Pasien ini selanjutnya menjalani trakeostomi oleh Departemen THT-KL Rumah Sakit Cipto Mangunkusumo.

\section{Kesimpulan}

Pada pasien anak, belum ada bukti berbasis medik yang memadai untuk menyimpulkan bahwa pemberian kortikosteroid profilaksis sebelum ekstubasi elektif akan mencegah stridor pasca-ekstubasi. Telaah sistematik dari

Tabel 4. Validitas studi prospektif

\begin{tabular}{lcccccc}
\hline Studi & $\begin{array}{c}\text { Allocation } \\
\text { concealment }\end{array}$ & $\begin{array}{c}\text { Intention to } \\
\text { treat analysis }\end{array}$ & Ketersamaran & Cuff-leak test & $\begin{array}{c}\text { Kriteria } \\
\text { ekstubasi }\end{array}$ & $\begin{array}{c}\text { Kriteria } \\
\text { reintubasi }\end{array}$ \\
\hline Harel (1997) & Ya & Ya & Ya & Ya & Ya & Tidak \\
Anene (1996) & Ya & Tidak & Ya & Ya & Ya & Ya \\
Tellez (1991) & Tidak jelas & Ya & Ya & Tidak & Tidak & Tidak \\
\hline
\end{tabular}


studi yang heterogen dengan metodologi yang kurang memadai seperti dalam tulisan ini hanya menghasilkan kecenderungan efek terapi, tetapi belum dapat digunakan sebagai suatu pedoman. Studi prospektif lebih lanjut perlu dilakukan untuk mengidentifikasi pasien berisiko tinggi yang mungkin memerlukan kortikosteroid profilaksis. Penelitian lanjutan dalam skala besar juga diperlukan untuk menentukan pilihan kortikosteroid, dosis, serta waktu dan metoda pemberian kortikosteroid pada ekstubasi elektif.

\section{Daftar pustaka}

1. Jaber S, Chanques G, Matecki S, Ramonatxo M, Vergne C, Souche B, dkk. Post-extubation stridor in intensive care unit patients: Risk factors evaluation and importance of the cuff-leak test. Intensive Care Med 2003;29:69-74.

2. Newth CJL, Venkataraman S, Willson DF, Meert KL, Harrison R, Dean JM, dkk. Weaning and extubation readiness in pediatric patients. Pediatr Crit Care Med 2009; 10:1-11.

3. Erginel S, Ucgun I, Yildirim H, Metintas M, Paspour S. High body mass index and long duration of intubation increase post-extubation stridor in patients with mechanical ventilation. Tohoku J Exp Med 2005;207:125-32.

4. Kurachek SC, Newth CJ, Quasney MW. Extubation failure in pediatric intensive care: A multiple-center study of risk factors and outcomes. Crit Care Med 2003;31:2657-64.

5. Harel Y, Vardi A, Quigley R, Brink LW, Manning SC, Carmody TJ, dkk. Extubation failure due to postextubation stridor is better correlated with neurologic impairment than with upper airway lesions in critically ill pediatric patients. Int J Pediatr Otorhinolaryngol 1997;39:147-58.

6. Anene O, Meert KL, Uy H, Simpson P , Sarnaik AP. Dexamethasone for the prevention of postextubation airway obstruction: A prospective, randomized, double-blind, placebo-controlled trial. Crit Care Med 1996;24:1666-9.

7. Tellez DW, Galvis AG, Storgion SA, Amer HN, Hoseyni M, Deakers TW. Dexamethasone in the prevention of postextubation stridor in children. J Pediatr 1991;1118:289-94.

8. Oxford Centre of Evidence-based Medicine. Oxford Centre for Evidence-based Medicine Levels of Evidence (March 2009). Diunduh dari: http://www.cebm .net/ index.asp $x$ ? $0=1025$.

9. Khemani RG, Randolph A, Markovitz BP. Corticosteroids for the prevention and treatment of post-extubation stridor in neonates, children and adults. Cochrane Database of Systematic Reviews 2009, Issue 3. Art. No.: CD001000. DOI: 10.1002/14651858.CD001000. pub3.

10. Markovitz BP, Randolph AG. Corticosteroids for the prevention of reintubation and postextubation stridor in pediatric patients: a meta-analysis. Pediatr Crit Care Med 2002;3:223-6.

11. McCaffrey J, Farrell C, Whiting P, Dan A, Bagshaw SM, Delaney AP. Corticosteroids to prevent extubation failure: a systematic review and meta-analysis. Int Care Med 2009;35:977-86.

12. Harel Y, Vardi A, Quigley R, Brink L, Manning S, Levin D. Dexamethasone does not prevent post extubation stridor in pediatric patients who failed extubation due to stridor. Crit Care Med 1995;23:A186. 